2020), approved in May 20I0. The policy has prioritized technical innovation and preparedness; but, like its predecessors, it lacks what is required for a reemerging China: namely, a vision to make cultural preparedness an equal priority to ensure China's well-rounded future global role. Still confined to a catch-up mentality, state policy continues to stress economic development, as the primary reference point in every part of the initiative-once again, leaving knotty issues of culture and values aside.

Modern universities are layered institutions, with technical apparatus on the surface but cultural values at the core. China's repeated attempts to import Western university models has occurred mostly on the level of technical apparatus. Based on the core values of the Western model, such as academic freedom and institutional autonomy, these have rarely been understood, let alone implemented. In the present great leap forward in Chinese higher education, what is missing is attention to cultural and institutional values. If Chinese universities cannot successfully integrate Chinese and Western values, the promise of the modern university in China will be limited. The question of culture is part of a much wider and more complex process of seeking an alternative to Western globalization. To be truly "world-class," Chinese universities must find an appropriate-one might even say uniquely Chinese-way to balance indigenous and Western ideas of the university.

\section{Foreign Influence, Nation- alism, and the Founding of Modern Chinese Universities}

\section{SHen Wenqin}

Shen Wenqin is professor in the Graduate School of Education, at Peking University, Beijing, China. E-mail: shenwenqin@pku.edu.cn.

$\mathrm{H}$ istorically, the development of higher education in various countries was often influenced by other countries' models. In a globalized world nowadays, policy learning between countries is very common. This article analyzes how different foreign models influenced the development of China's higher education system, during I9I7-I927, and how nationalism became a driving force of this reform.
Although China has a long tradition of higher education, the first group of Chinese universities came into being around the turn of the 2oth century-led by Beiyang Gongxue (1895), Nanyang Gongxue, Capital Metropolitan University (predecessor of Peking University, I896), and Shanxi University (I902). Until I9II, these universities generally adhered to the ancient Confucian traditions of learning.

It was in the years after the Republican revolution of I9II-a movement led by Sun-Yat Sen, which toppled the two-thousand, year-old Qing Dynasty-that Chinese higher education would truly begin to change. In the postrevolutionary era, Chinese leaders would look to "modernize" Chinese higher learning.

\section{German Model}

Cai Yuanpei, appointed as the first minister of education for the new Republic of China in I9I2, looked west for models of higher education. One of Cai's first moves was the drafting of "The Regulation of the Universities" (DaXue Ling), which outlined the modern disciplinary system in Chinese universities. Most importantly, this document made research and postgraduate education as central to the university mission.

But it was not until Cai became president of Peking University, in late I9I6, that his idea of a university with a research mission would be fully realized. In I9I6, the university was not small, but most students were drawn to the professions - namely law and business-and guided by a sense of "careerism." The university's faculty similarly did not value the research enterprise. Cai, in his inaugural address, sought to change this mentality, encouraging students to work hard and attend to scholarship — not careers. He proclaimed the university to be "a place to investigate advanced knowledge."

From where did Cai's intense interest in research and scholarship arise? To begin with, Cai had studied in Germany from I907 to I9II. During this time he became familiar with the German university system and admired the German ideals of academic freedom, original research, and knowledge for its own sake. In I9I7, seminars along the lines of those in German universities were founded in the division of humanities, social sciences, and natural sciences. Cai saw such seminars as places for "the professor and graduate students or advanced students to do research together." By I9I8, I4 8 students (80 postgraduates and 68 senior undergraduates) participated in the seminar system.

Faculty research was another matter. In I9I9, to encourage professors to engage in scientific research, Cai founded The Journal of Peking University, a forum for the publication of faculty research. With the addition of another academic journal, the Chinese Social Sciences Quarterly, in 1922, the 
Peking faculty began to publish more widely. Within a few years, Peking University had come to resemble a Chinese version of Johns Hopkins University, an institution complete with research seminars, faculty governance structures, and professional journals.

\section{American Model}

As more and more Chinese returned from study abroad in the United States in the I920s, the American model also became influential. In I9I8, Yanxiu and Zhang Boling, after visiting the United States and conducted a survey of American higher education, founded Nankai Universitya private institution reflective of American models. From December I9I9 to April I920, a group of normal school principals and local education authorities, headed by Chen Baoquan and Yuan Xitao, visited American universities for more than five months and wrote a report on American higher education-offering suggestions for reform in China. Many other young Chinese students and scholars studied in the United States during this time, absorbing the patterns of American higher education and bringing back ideas for change in their home country. Some, including Guo Bingwen, Jiang Mengling, Hu Shi, Zhao Yuanren, and Zhu Kezhen (later president of Zhejiang University) became prominent reformers in Chinese higher education in the ig2os.

\section{It was in the years after the Republican revolution of 1911-a movement led by Sun-Yat Sen, which toppled the two- thousand, year-old Qing Dynasty_that Chinese higher education would truly begin to change.}

As a result of such transnational travel and intellectual exchange, a number of features of American higher education could be found in China by the end of the I920s: private universities, the organization of academic work into departments, the elective curriculum for undergraduates, the credit-hour system, and the board of trustees' governance structure. Like Cai, other Chinese higher education leaders used their experience abroad to shape their own institutions in China. For instance, Guo Bingwen became the president of Southeast University in I92I, while Jiang Mengling became the executive president of Peking University in I923. Both men received their doctoral degrees from Columbia University's Teachers College in I9I4 and I9I8, respectively. The influence of the American model was not confined to these two universities. In I929, Sun Yat-sen University set up a board of trustees that clearly borrowed from the American model.

\section{Nationalism as a Driving Force}

In less than a decade, from Peking University's reform under Cai in I9I7 to the founding of Sun Yat-sen University in I924, a modern system of higher education, emphasizing research and academic freedom, had emerged in China. Why were these Chinese higher education leaders so eager to establish "modern" universities in China? One explanation is that figures like Cai Yuanpei, Jiang Mengling, Guo Bingwen, and others were all patriots: "To save the nation through education and scholarship" was their creed. For example, though they had learned from Western models, they supported a policy of reclaiming the management of China's Christian universities from foreign presidents. Making China a free, democratic, and prosperous country was the common aspiration of Chinese intellectuals of that generation. During the I9IOs and I920s, the newly established Republic of China was fragile, as warlords and political fragmentation wracked the country. These leaders were convinced that, just as the University of Berlin and other universities had made Germany into a powerful empire, so too would great Chinese universities lead China toward prosperity and freedom.

\section{DOMESTIC TRADition}

Nevertheless, it would be wrong to suggest that modern Chinese higher education development was merely a copy of the Western model. The task of establishing a fullfledged research university was an expensive one, challenging even in times of prosperity-let alone times of political instability. Chinese reformers could only go so far in implementing Western models. For example, although Cai and other educational leaders realized that graduate education was the core of the modern university, they could not afford to establish full-graduate schools. Instead, they relied on research seminars and institutes. Similarly, because they often could not afford expensive laboratory equipment, research and study in the humanities and theoretical sciences took precedence over direct research in the physical and applied sciences.

Chinese education leaders sought to reinvigorate their country's higher education system by combining foreign and domestic ideas. For example, the Chinese Studies Center at Tsinghua University, established in I925, made its work "adopting both the strength of modern schools and ancient Chinese Academy (Shu Yuan)." The ancient tradition of open debate and close interaction between teachers and students flourished there alongside some Western influences. The reforms between I9I7 and I927 were only 
a beginning, yet they laid the foundation for the future growth of research universities in China. These years would be one of the first of many instances of Chinese educational leaders borrowing from abroad in higher education in the 2oth century.

\section{LOOKING FORWARD}

Today's Chinese higher education reformers still pay close attention to higher education in other countries, yet reformers have never been able to completely cast off ancient traditions or ignore the vicissitudes of state politics. In the early 2Ist century, the biggest challenge for us is to establish a Chinese model of higher education and gain comparative advantage.

\section{The Problem with Public University Salaries in Kenya}

\section{ISHMael I. Munene}

Ishmael I. Munene is associate professor in the Educational Leadership Department, Northern Arizona University. E-mail: Ishmael.Munene@ nau.edu.

$\mathrm{T}$ he fourth faculty strike in two years, over salaries in Kenya's public universities, ended in March. If history is a guide, the truce is merely a strategic retreat before another battle. Soon drumbeats of war will be sounded for another night of long knives. The frequent high-octane skirmishes over university salaries have become toxic to the nation and disruptive to academic programs. So, what ails public university salaries in Kenya and how can the problems be ameliorated once and for all?

The discontent over university salaries stems from a triumvirate of three interrelated factors: union-initiated cost-of-living salary adjustments, merit pay, and equity. The failure by national educational authorities and the university administrators to resolve the contradictions arising from these issues only serves to amplify the stakes in salary adjustments and ensures that unions and universities are locked eternal combat. Key to resolving the incessant battle is moderating the enormous influence of Collective Bargaining Agreements in compensation enhancement in public universities.

\section{Collective Bargaining Agreements}

No doubt, trade unions play a crucial role in setting the low- er and upper limits of university salaries. The unions have a good grasp of the macro- and micro-economic conditions, affecting the purchasing power of their member's income. The 33 percent salary and I7 percent housing-allowance increase negotiated in 2014 between the state universities and three unions-the University Academic Staff Union (representing the faculty), the Kenya University Staff Union (representing the professional staff), the Kenya Union of Domestic, Hotels Educational Institutions, Hospitals and Allied workers (representing the junior staff)—shows the dexterity of the unions in cushioning their members from the deleterious effects of inflation. Under the agreement, the most senior professors earn a consolidated monthly pay of around US\$3,300, while their junior counterparts make US \$I,757. With an average inflation rate of I2 percent and with no free public education for dependents, these salaries are barely sufficient to sustain a middle-class lifestyle for the academic staff. Even with the increase, the salaries still lag behind their counterparts in the judiciary and legislature. Twenty years ago a senior university professor, a judge, and a member of parliament earned similar monthly pay and benefits. Today, a member of parliament takes home around US\$9,400, while a judge makes US\$7,000 per month.

These across-the-board salary increases, along with the accompanying annual increases based on years of service, have exerted severe pressure on the government exchequer and university treasuries. So much so that universities diverted portions of the funds meant for payment of the new salaries toward debt clearance and facilities maintenance, thereby occasioning the latest industrial strife.

\section{Pay for Performance}

While the unions have proved to be adept at reading the macro-level economic conditions, they are very poor readers of merit-pay systems in universities. Due to the stranglehold of Collective Bargaining Agreements, lecturers and professors in the same grade earn similar salaries, despite differing levels of productivity. In other words, "pay for performance" is anathema in Kenya's public university system. In a merit-based system, salary increases are also weighted on performance indicators in the areas of teaching, scholarship, and community service. The system appeals to the values of individualism, achievement, and rewards. In absence of a merit-based compensation system in Kenya today, a highly productive professor or lecturer will mainly earn the same salary as their nonproductive counterpartslongevity in rank being the only condition for annual salary increments.

To reward merit, university mandarins need to devise annual pay-for-performance salary increases weighted in accordance with teaching, scholarship, and community 